\title{
RESPONSE
}

\section{Pains of Imprisonment, Everyday Deprivation and the Meanings of Post-Prison Kevin Walby}

Drisons and jails abolish our sense of our selves, through loss of autonomy, P lack of material possessions, loss of say over sexual and personal relationships, reduced personal security, and forced racialization. Today's prisons and jails force people to pick sides, assault other sides, which is equally an assault on the self. These are the pains of imprisonment. They are real and lasting. The contributions found in this iteration of the Journal of Prisoners on Prisons (JPP) make it clear that these pains continue to be felt on the inside and post-prison as well.

Anonymous reflects on the devastating consequences of solitary confinement. His account of isolation and dispossession is chilling. Michael Johnson Jr. provides insight into sexualized prison violence and the issue of male rape. His story shows how unsettling and distressing such a brief violent encounter can be. Next, Robert Shoemaker, Brandon Willis and Angela Bryant consider the importance of education in prisons. Perhaps most worrying is that opportunities for education in prisons continue to dry up. Next, Daniel Luff and Greg Newbold raise questions about the culture of risk assessment in prisons and whether risk assessments do more harm than good. Exploring the vantage point of convict criminology, Alan Mobley demonstrates that shame built-up as a result of the pains of imprisonment can be immobilizing and upsetting. All the pieces in this issue of the JPP provide insight into the pains of imprisonment.

Prison agencies, including Canadian ones, tell us all these pains are offset by programing or a focus on rehabilitation. However, recent and significant changes at the federal level in Canada suggest otherwise. Since the contributors focused on the United States and other countries, I will provide context by focusing on Canada. Major changes federally in the Canadian context include rapid population growth. There are new precedents in all regions, such as double bunking in cells designed for single occupancy. In the Prairie region, fights and sexual assaults are up 60 percent. There are now more murders, more lockdowns, self-harm, and more administrative segregation, as well as double bunking in segregation in our federal penitentiaries. Prisoners and their advocates, but also guards have made complaints. All of this is according to the 
Office of the Correctional Investigator (OCI) of Canada's annual report for 2012-2013.

This is a cycle of abuse. It starts with the pains of imprisonment that the authors in the JPP examine so clearly. The abuse is amplified by population growth and poor conditions. It is followed by segregation as punishment and segregation as means to manage prison populations. More use of segregation to manage this cycle means more abuse. It is almost as if the Government of Canada led by Conservative Prime Minister Stephen Harper thinks segregation is the solution to Canada's prison problems. We also see over-reliance on segregation to manage mental health issues, a disproportionate number of suicides in segregation, and a disproportionate number of First Nations men and women in segregation.

In Canada, we are witnessing exceptional change toward the conservative delusion of total segregation. What is happening in Canada's carceral state today will for certain inflame the pains of imprisonment tomorrow. As bad as that sounds, provincial jails are as bad or worse. Scholars in mainstream journals and in the JPP too over the years have tended to zero in on prisons rather than jails. The pains of being jailed certainly are long-term since some people do more time total in jail than in prison, where they are often moved around more frequently. People never know who they are in a cell with and staff hardly know either. Half or more of those held in jails are simply awaiting trial. This is the remand crisis. In some jurisdictions 85 percent of people in jail are waiting on the courts. There are class-dimensions, of course. Those in remand are often the subset of the presumed innocent who cannot afford to pay bail. And jails are becoming more chaotic in Canada as a result of several dozen changes to criminal law recently rolled out by Harper's Conservatives, sometimes at the request of their provincial counterparts.

These are big problems that seem to be getting worse in Canada. However, as the authors in this issue of the JPP point out, sometimes the mundane hurts more post-prison. Everyday deprivation is what many prisoners say hurts the most. In prison and jail you have no say over any thing. For people on the outside, when you wake-up you have a say over when to turn the lights on, you know where the light switch is, you have a say over which lights to turn on, where to step. Your place in the world is full of things and you have a say over them, how you will move down the hall, what room you go to next. Your relationship with the world around you is not a problem. But in prison and jail, it is made a problem by guards, administrators and 
other prisoners. I was trying to think of the common theme of all the JPP writings about the pains of imprisonment. One underlying feature is this: in prison and jail, you are deprived the fundamental good to have a say over the mundane aspects of life. Your relationship with things, with the walls around you, where you are standing - you have little say over any of it. As Anonymous puts it in this issue, you "can make no choices for yourself". Light switches on walls, how to move down a hallway, these are taken for granted outside. But when you cannot reach out and touch them, be in control of your self, your body and relationship to the world, it collapses you. Everyday deprivation. It is as lasting in its effects as the most bloody violence. So when people get out and we talk about pains of re-entry, these simple things can become overwhelming.

The exceptional. The mundane. The total range of pain that imprisonment causes. If we want to understand imprisonment we must map out the exceptional changes and trends, include accounts of the jail, and not overlook the little things that make prisons and jails make so little sense. The damaging effects of imprisonment will only be exacerbated by big changes we are seeing in Canada's carceral state. The articles that make up this volume of the JPP are courageous in tackling these issues that at times seem incomprehensible.

The other meaning of post-prison, of course, is making a world where we do not do this to one another anymore. The carceral state in Canada, in the United States, everywhere, is abusive. We must then try to commit to abolishing all organizations that attempt to abolish our sense of our selves. 